\title{
Socioeconomic Conditions in Childhood and Mortality in Adulthood - a Follow-up Study in Two Areas of Finland 1959-74
}

\author{
VEIJO NOTKOLA
}

\section{Introduction}

It has been shown in several studies that there are marked regional differences in mortality in Finland and in other countries (Valkonen and Niemi, 1978; Notkola, 1980; Shaper et al., 1981). However, the causes of these differences are in most cases unknown. In Finland the regional differences for coronary heart disease (CHD) are most marked.

There are also clear social class differences in mortality in different countries (Antonovsky, 1967; Marmot et al., 1978; Näyhä, 1977; Valkonen, 1982). Mortality has been highest in lower social classes. Causes of these differences can not be totally explained.

In my licentiate work (Notkola, 1980) I concluded that the high mortality in East-Finland during the $1950 \mathrm{~s}$ and $1960 \mathrm{~s}$ is connected to the difficult living conditions at the beginning of this century and during the 1920 s and 1930 s. Similar results can be found in Norway, too. In his study of high mortality in North Norway, Forsdahl $(1977,1978)$ showed that high mortality in North Norway during 1960 s and 1970 s might have been due to poor living conditions in the same areas at the beginning of this century. According to these studies (Forsdahl, 1978 or Notkola, 1980) coronary mortality in particular was high in those areas where living conditions were bad at the beginning of this century.

The studies of Forsdahl as well as my own have, however, been based on municipality or county data. It is not possible to confirm from ecological data that the bad living conditions in childhood could later cause higher mortality.

In explaining differences in mortality from coronary heart disease by social class in adulthood, it is also suggested that factors connected to poor living conditions in childhood such as childhood nutrition, might explain in part the increased mortality of lower social classes (Rose and Marmot, 1981).

The aim of the present study is to determine whether there is, in Finland, a relationship between socioeconomic conditions in childhood and mortality in adulthood. Moreover the questions of whether or not the relationship is similar due to different causes of death and whether or not it is similar both in East and in West Finland are examined.

The mortality differences are also analyzed by body height. There are some epidemiological studies where the risk of coronary death was shown to be higher among shorter subjects than taller ones (Marmot et al., 1978). Again it is suggested that the higher coronary mortality of shorter subjects could be in part explained by factors connected to living conditions in childhood. The aim is to determine whether the mortality of shorter subjects is higher than taller ones also in Finland and to discuss possible causes of mortality differences. 
The data and methods

\section{East - West study}

The study is based partly on the data of the East-West study in Finland, which was part of the Seven-Countries Study done by Keys and others (Keys, 1980). The study areas were Ilomantsi in East Finland and the municipalities of Pöytyä and Mellilä in West Finland. The initial examination in 1959 covered $99.3 \%$ of the eligible men (823) in the Ilomantsi municipality and $97.0 \%(888)$ in the municipalities of Pöytyä and Mellilä (Karvonen et al.; 1967; Karvonen et al., 1970). During the follow-up time (1959-1974), the men born in 1900-1919 in both areas were medically examined four times (1959, 1964, 1969 and 1974). The participation rate has always been over $96 \%$ of those still alive.

In both areas the men had similar occupational and educational backgrounds. Over $80 \%$ in both areas were employed in farming and logging. The structure of farming, however, was very different in the two areas. The average farm size of peasant farmers was 21.5 hectares in the year 1910 in the west, while the same figure in the east was 4.6 hectares. In the year 1959 the average farm size was still clearly smaller in the east than in the west. The eastern area had been one of the poorest areas in Finland and the western area one of the wealthiest. For example, in the year 1901 the housing density was 3.3 persons per room in the eastern area. This compared to 1.9 persons per room in the western area.

\section{Socioeconomic conditions in childhood}

The socioeconomic conditions in childhood were measured by occupation and farm size of the father and, if the father was not alive, the same information for the mother was used. The occupation of parents was collected from parish registers and the farm size information from the study of the Committee of Landless People data and from the agricultural censuses of $1910-1930$. The study of the Committee done in 1901 can be compared to the censuses in Finland (Gebhard, 1913).

The information of parents' occupations and parents' farm sizes was combined and following socioeconomic groups were formed:

1) Farmers (Highest socioeconomic category)

2) Small farmers

3) Landless (Lowest socioeconomic category)

4) Craftsmen

5) Others and missing

The group of farmers included all those whose fathers' or mothers' occupations were farmer, crofter, farm worker, etc. or occupation was unknown and the farm size was over four hectares (cultivated land).

Small farmers included the same occupational groups as farmers, but the size of farm was over half a hectare but under four hectare.

The landless included the same occupational groups as farmers but the size of farm was under half a hectare.

The craftsmen included artisans and other craftsmen such as journeymen, innkeepers, millers, parish clerks, etc. However, the gentlefolk (such as teachers) were not included. There were thirteen men whose parents belonged to this groups. Because the classification of these men in the other socioeconomic groups would be problematic, these men were classified in the group »others and missing» (Table 1). 
$\mathrm{T}$ a b l e 1. Percentages of men by socioeconomic conditions in childhood and area

\begin{tabular}{lccccc}
\hline & \multicolumn{3}{c}{ East } & & \multicolumn{3}{c}{ West } \\
\cline { 2 - 3 } \cline { 5 - 6 } & & $\mathrm{N}$ & & $\mathrm{N}$ \\
\hline Farmers & $18.8 \%$ & $(155)$ & & 41.3 & $(367)$ \\
Small farmers & 45.0 & $(370)$ & & 19.1 & $(170)$ \\
Landless & 22.0 & $(181)$ & & 28.8 & $(256)$ \\
Craftsmen & 6.7 & $(55)$ & & 6.1 & $(54)$ \\
Others and missing & 7.5 & $(62)$ & & 4.6 & $(41)$ \\
\hline All & 100.0 & $(823)$ & 100.0 & $(888)$ \\
\hline
\end{tabular}

Body height 1959

The body height was measured as a part of the medical examination in 1959. The data was divided into three equal categories according to body height (Table 2).

T a b l e 2. Percentages of men by body height and area in 1959

\begin{tabular}{|c|c|c|c|c|}
\hline Height & \multicolumn{2}{|c|}{ East } & West & $\mathrm{N}$ \\
\hline$-167 \mathrm{~cm}$ & $46.7 \%$ & (384) & 25.0 & (222) \\
\hline $168-172$ & 29.9 & (246) & 29.3 & (260) \\
\hline $173-$ & 21.3 & (175) & 40.9 & (363) \\
\hline Missing & 2.2 & ( 18$)$ & 4.8 & ( 43) \\
\hline All & 100.1 & (823) & 100.0 & (888) \\
\hline
\end{tabular}

Classification of deaths, age and period

The following measurements of mortality were used: total mortality, cardiovascular mortality, coronary mortality and mortality due to causes other than cardiovascular diseases.

The identification of deaths was based on a careful analysis of the circumstances of death (Karvonen et al., 1970). Age at the beginning of every period was classified in the following way: $40-49,50-54,55-59,60-$. The follow-up periods were 1959-64, 1964-69 and 1970-1974.

The risk population

Men without ischemic heart disease in 1959 formed the CHD-free population, and this group was considered as the risk population (Notkola et al., 1984).

\section{Statistical method used}

The measurement of risk for different categories was expressed in the following formula: 
Relative risk: absolute risk of the »exposed group» divided by absolute risk of reference group.

The log-linear model was used (Holford, 1980) and the estimation of relative risks was made using the Poisson model in Glim (Baker and Nelder, 1980). The statistical significance among the categories was tested using likelihood ratio statistics (asymptotic chi-squared deviances).

\section{Results}

The total number of deaths was 387 , of which 146 could be classified as caused by coronary heart disease, 196 from cardiovascular diseases and 188 from causes other than cardiovascular diseases. The crude total mortality was thus 19.3 , the cardiovascular mortality 9.8 , the coronary mortality 7.3 and mortality due to causes other than cardiovascular diseases 9.4 per 1000 person-years.

A problem in analyzing mortality differences by socioeconomic conditions in childhood or by body height was that the number of deaths was quite small (Table 3). In particular, the number of coronary deaths was small. This means that possible mortality differences have to be great before differences are also statistically significant.

$\mathrm{Ta} \mathrm{ble} \mathrm{3.} \mathrm{The} \mathrm{number} \mathrm{of} \mathrm{deaths} \mathrm{by} \mathrm{cause} \mathrm{of} \mathrm{death} \mathrm{and} \mathrm{follow-up} \mathrm{time} \mathrm{in}$ months by socioeconomic conditions in childhood, body height and area.

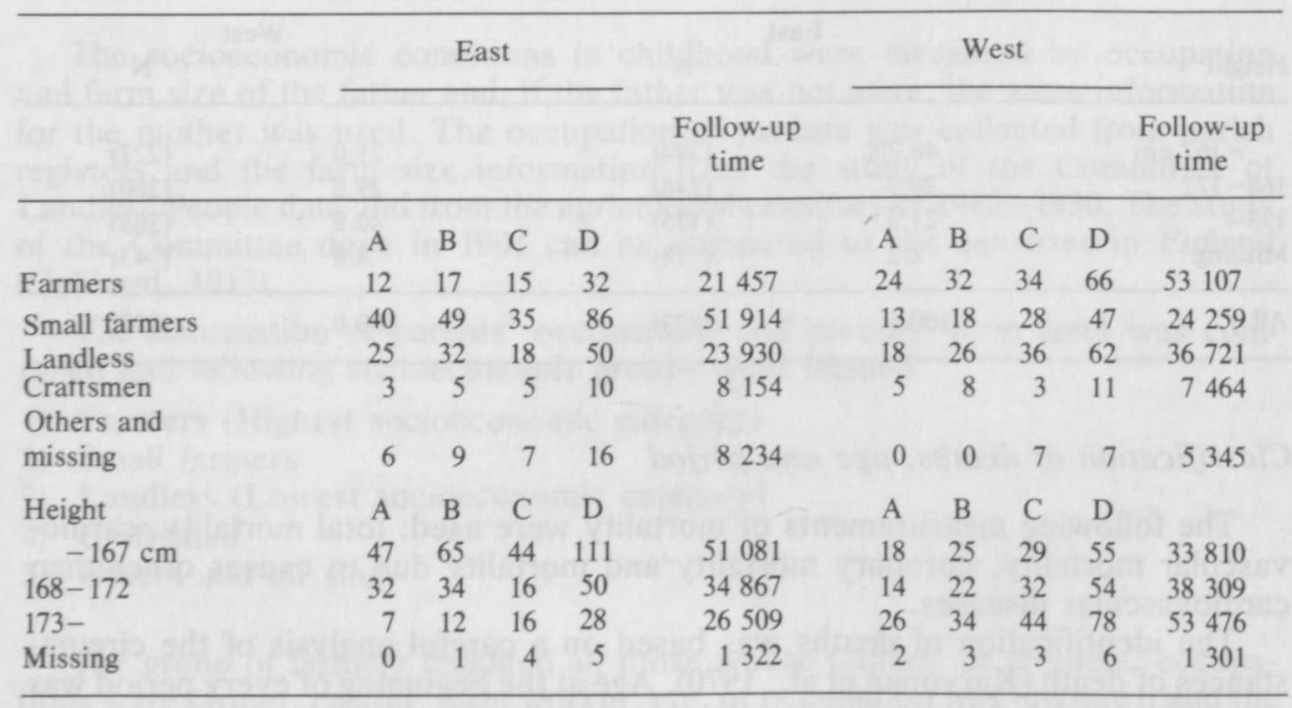

$\mathrm{A}=$ Coronary heart disease

$\mathrm{B}=$ Cardiovascular diseases

$\mathrm{C}=$ Other than cardiovascular diseases

$\mathrm{D}=$ Total deaths

\section{Regional mortality differences}

Mortality was higher in the eastern than in the western area. However, the different diseases behaved differently. In total mortality the east-west difference was statistically significant, but small. 
In relative risk of death due to causes other than cardiovascular diseases there was not any difference between east and west at all. The relative risk of coronary death or death due to cardiovascular diseases was significantly higher in East than in West-Finland (Table 4). The result showed very clearly than the east-west mortality difference was due to mortality differences in cardiovascular diseases, in particular due to coronary heart disease.

T a b l e 4. Relative risk of death by cause of death and area in Finland 19591974. Adjusted for age and period.

\begin{tabular}{lcccc}
\hline & East $(\mathrm{R})$ & West & \multicolumn{2}{c}{$\begin{array}{c}\text { East-West } \\
\text { difference is significant }\end{array}$} \\
\hline A & 1.00 & 0.57 & at the level & 0.01 \\
B & 1.00 & 0.61 & not significant & 0.01 \\
C & 1.00 & 1.10 & & 0.05 \\
D & 1.00 & 0.81 & \\
\hline
\end{tabular}

$\mathrm{R}=$ Reference group

$\mathrm{A}=$ Coronary heart disease

$\mathrm{B}=$ Cardiovascular diseases

$\mathrm{C}=$ Other than cardiovascular diseases

$\mathrm{D}=$ Total mortality

\section{The effect of socioeconomic conditions in childhood}

In the case of total mortality, the relative risk of death was increased among the landless and small farmers (Table 5, p. 154). The effect of socioeconomic conditions in childhood was not significant, but the relative risks for the landless and small farmers were systematically higher than the relative risk of farmers.

However, the increased risk of the landless and small farmers was caused by different diseases in the east than in the west. In the east the increased risk of the landless and small farmers was caused by cardiovascular diseases, in particular coronary heart disease, but in the west also the relative risk of death from other than cardiovascular diseases was increased among the landless and small farmers compared to farmers.

The differences in relative risks by socioeconomic conditions were not statistically significant. The relative risks of the landless and small farmers were, however, increased very systematically in the east. Moreover, in coronary heart disease morbidity there were also similar differences by socioeconomic conditions in childhood to those in mortality (Notkola et al., 1984).

\section{The effect of body height}

In the western area there was not any difference in mortality by body height, but in the eastern area the relative risks of shorter men were clearly increased. The increase in total mortality was caused by cardiovascular diseases and evidently in particular coronary heart disease. The effect of final body height in the east was significant at the level 0.01 in the case of coronary heart disease.

A very interesting phenomenon was that among the tallest men the relative risk of death was higher in the western than in the eastern area. The result was independent of the cause of death. 
$\mathrm{T}$ a b l e 5. Relative risk of death by socio-economic conditions in childhood, cause of death and area in Finland 1959-1974. Adjusted for age and period.

\begin{tabular}{|c|c|c|c|c|c|c|c|c|}
\hline & \multicolumn{2}{|c|}{ A } & \multicolumn{2}{|c|}{ B } & \multicolumn{2}{|c|}{ C } & \multicolumn{2}{|c|}{ D } \\
\hline & East & West & East & West & East & West & East & West \\
\hline 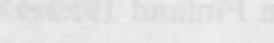 & 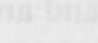 & & & & $x^{2}$ & 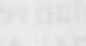 & the & 2 \\
\hline Farmers & $1.00 \mathrm{R}$ & 0.73 & $1.00 \mathrm{R}$ & 0.69 & $1.00 \mathrm{R}$ & 0.83 & $1.00 \mathrm{R}$ & 0.75 \\
\hline Small farmers & 1.44 & 0.87 & 1.25 & 0.85 & 1.00 & 1.48 & 1.16 & 1.17 \\
\hline Landless & 1.88 & 0.85 & 1.69 & 0.86 & 1.07 & 1.36 & 1.40 & 1.09 \\
\hline Craftsmen & 0.69 & 1.09 & 0.82 & 1.23 & 0.93 & 0.53 & 0.87 & 0.90 \\
\hline Others and missing & 1.17 & - & 1.22 & - & 1.07 & 1.70 & 1.15 & 0.79 \\
\hline
\end{tabular}

$\mathrm{R}=$ Reference group

$\mathrm{A}=$ Coronary heart disease

$\mathrm{B}=$ Cardiovascular diseases

$\mathrm{C}=$ Other than cardiovascular diseases

$\mathrm{D}=$ Total mortality

$\mathrm{A}=$ Coronary heart disease

$\mathbf{B}=$ Cardiovascular diseases

$\mathrm{C}=$ Other than cardiovascular diseases

$\mathrm{D}=$ Total mortality
Effect of socioeconomic conditions in whole data

Not significant

Not significant

Not significant

Significant at level 0.10

Effect of interaction between area and socioeconomic conditions

Not significant

Significant at level 0.10

Not significant

Not significant

$\mathrm{T}$ a b l e 6 . Relative risk of death by body height, cause of death and area in Finland 1959-1974. Adjusted for age and period.

\begin{tabular}{|c|c|c|c|c|c|c|c|c|}
\hline & \multicolumn{2}{|c|}{ A } & \multicolumn{2}{|c|}{ B } & \multicolumn{2}{|c|}{ C } & \multicolumn{2}{|c|}{ D } \\
\hline & East & West & East & West & East & West & East & West \\
\hline$-167 \mathrm{~cm}$ & 3.19 & 1.64 & 2.55 & 1.31 & 1.27 & 1.13 & 1.85 & 1.22 \\
\hline $168-172$ & 3.21 & 1.15 & 1.98 & 1.05 & 0.69 & 1.14 & 1.24 & 1.09 \\
\hline $173-$ & $1.00 \mathrm{R}$ & 1.65 & $1.00 \mathrm{R}$ & 1.25 & $1.00 \mathrm{R}$ & 1.21 & $1.00 \mathrm{R}$ & 1.22 \\
\hline
\end{tabular}

$\mathrm{R}=$ Reference group

$A=$ Coronary heart disease

$\mathrm{B}=$ Cardiovascular diseases

$\mathrm{C}=$ Other than cardiovascular diseases

$\mathrm{D}=$ Total mortality

$\mathrm{A}=$ Coronary heart disease

$\mathrm{B}=$ Cardiovascular diseases

$\mathrm{C}=$ Other than cardiovascular diseases

$\mathrm{D}=$ Total mortality
Effect of body height

Not significant

Significant at level 0.10

Significant at level 0.05

Significant at level 0.01

Effect of interaction between area and body height

Significant at level 0.01

Significant at level 0.05

Not significant

Not significant 


\section{Discussion}

According to the results the relative risk of death was increased for those born as landless or as small farmers both in the east and in the west. In the east the increased risk was caused by cardiovascular diseases but in the west it was caused mainly by other than cardiovascular diseases.

The body height was an important variable just in the eastern area, where the relative risks of shorter men were increased systematically due to cardiovascular diseases, in particular due to coronary heart disease.

The results in the case of both variables supported the suggestion that poor living conditions in childhood increase cardiovascular, in particular coronary heart disease mortality in adulthood. The relationship was clearer in the eastern area. This result leads us to suppose that, at least in part, the causes of development of coronary heart disease are different in the East than in the West Finland.

The effect of body height was also statistically significant. Socioeconomic conditions in childhood and body height were both at least in part indicators of living conditions in childhood. Why, however, was the effect of socioeconomic conditions in childhood not significant? One possible reason would be that the body height is a more reliable variable than socioeconomic conditions in childhood.

Although the results suggested that living conditions in childhood affect mortality in adulthood there are many other factors involved. The mortality differences by height or by parents' socioeconomic position could also be caused by factors other than those connected to living condition in childhood.

The increased risk of death for the landless, small farmers and those of short stature was caused by cardiovascular diseases. In the etiology of cardiovascular diseases the role of "risk factors" is a very important one. The increased risk of cardiovascular death in adulthood might be due to these "risk factors, " such as differences in smoking, blood pressure or serum cholesterol concentration. In addition, the role of genetic differences cannot be excluded. The increased risk of coronary death among shorter men but also among the landless and small farmers might be due to some genetic factor, too.

If living conditions in childhood have some independent effect on mortality in adulthood the possible variables would be deficient nutrition in childhood, heavy physical work at a very young age or probably also higher incidence of infections during childhood.

The open question is why the relative risk of death for shorter men increased just in the eastern area and not in the western one. The probable explanation for this is that in the west where the standard of living has been higher than in the east, the body height is determined just by genetic factors but in the east it is also affected by living conditions in childhood.

\section{Acknowledgements}

This study was supported by grants from the Punainen Sydän Foundation of the Lions International of Finland and the Yrjö Jahnsson Foundation. I am indebted to Dr. Sven Punsar and Dr. Martti J. Karvonen for the opportunity of using the East-West data. 


\section{References}

Antonovsky, A. (1967). Social class, life expectancy and overall mortality. Milbank Memorial Fund Quarterly 45: 31-37.

Baker, R. J. and Nelder, J. A. (1978). The GLIM System, release 3, generalised linear interactive modelling. Oxford.

Forsdahl, A. (1977). Are poor living conditions in childhood and adolescence an important risk factor for arteriosclerotic heart disease? British Journal of Preventive and Social Medicine 31: 91-95.

- (1978). Space living conditions in childhood and subsequent development of risk factors for arteriosclerotic heart disease? Journal of Epidemiology and Community Health 32: 34-37.

Gebhard, J. (1913). Maanviljelysväestö. Sen suhde muihin elinkeinoryhmiin ja sen yhteiskunnallinen kokoonpano. Tilattoman väestön alakomitea. Tilastollinen tutkimus yhteiskunta-taloudellisista oloista Suomen maalaiskunnissa v. 1901. Helsinki.

Holford, T. R. (1980). The analysis of rates and of survivorship using log-linear models. Biometricks 36: $299-305$.

Karvonen, M.; Blomqvist, G.; Kallio, V.; et al. (1967). Men in rural East and West Finland. In: Epidemiological studies related to coronary heart disease: characteristics of men aged 40-59 in seven countries, edited by Keys et al. Acta Medica Scandinavica. Suppl. 460: 169-190.

- ; Orma, E.; Punsar, S.; Kallio, V.; Arstila, M.; Luomanmäki, K. and Takkunen, J. (1970). Five year experience in Finland. In: Coronary heart disease in seven countries, edited by A. Keys. American Heart Association Monographs 29: 52-62.

Keys, A. (1980). Seven countries. A multivariate analysis of death and coronary heart disease. London.

Marmot, M. G.; Adelstein, A. M.; Robinson, N. and Rose, G. A. (1978). Changing social-class distribution of heart disease. British Medical Journal 2: 1109-1112.

Notkola, V. (1980). Alueelliset kuolleisuuserot Suomessa 1950-1975. Department of Sociology, University of Helsinki. Research reports No. 218.

- ; Punsar, S.; Karvonen, M. and Haapakoski, J. (Unpublished). Socioeconomic conditions in childhood and coronary heart disease mortality and morbidity in adulthood in rural Finland.

Näyhä, S. (1977). Social group and mortality in Finland. British Journal of Preventive Medicine 31: $231-237$.

Rose, G. and Marmot, M. G. (1981). Social class and coronary heart disease. British Heart Journal 45: $13-9$.

Shaper, A. G.; Pocock, S. J.; Walker, M.; Cohen, N. M.; Wale, C. J. and Thompson, A. G. (1981). British regional heart study: cardiovascular risk factors in middle-aged men in 24 towns. British Medical Journal 283: 179-186.

Valkonen, T. and Niemi, M-L. (1978). Keski-ikäisen väestön kuolleisuus Suomessa vuoden 1950 jälkeen. Sosiaalilääketieteellinen Aikakauslehti 15: 215-226.

- (1982). Psychosocial stress and sociodemographic differentials in mortality from ischaemic heart disease in Finland. Acta Medica Scandinavica. Suppl. 660: 152-164. 